\title{
Transfected rat islet tumour cells express mouse major histocompatibility complex class I antigens functionally
}

\author{
Applicable as "pseudo-syngeneic" targets in the multiple low-dose streptozotocin diabetes model \\ P.Serup ${ }^{1}$ and J.Schøller ${ }^{1,2}$ \\ ${ }^{1}$ Hagedorn Research Laboratory, WHO Collaborating Centre for Research and Training in the Pathogenesis of Diabetes Mellitus, Gentofte, \\ and ${ }^{2}$ Institute for Experimental Immunology, University of Copenhagen, Copenhagen, Denmark
}

\begin{abstract}
Summary. Rat insulinoma cells clone $5 \mathrm{AH}-\mathrm{B}$, were transfected by electroporation with the gene encoding the mouse major histocompatibility complex class I antigen $\mathbf{H}-2 \mathrm{~K}^{\mathrm{b}}$, whereupon stable transfectants were selected and analysed. Data from flow cytometric analyses using three different $\mathrm{H}$ $2 \mathrm{~K}^{\mathrm{b}}$ specific monoclonal antibodies and functional assays using $\mathrm{H}-2 \mathrm{~K}^{\mathrm{b}}$ specific alloimmune cytotoxic $\mathrm{T}$ cells revealed that the encoded $\mathrm{H}-2$ antigen was expressed in a functional manner. Similar experiments employing the monoclonal antibody $\mathrm{OX}-18$, which recognizes rat major histocompatibility class I molecules, and xenoimmune cytotoxic T cells specific for the endogenously expressed RT1 ${ }^{\mathrm{g}}$ antigen showed that functional expression of the $\mathrm{RT} 1^{\mathrm{g}}$ antigen was maintained. However, a down-regulation of the expression was observed in $\mathrm{H}-2 \mathrm{~K}^{\mathrm{b}}$ positive transfectants, whereas normal expression was retained in $\mathrm{K}^{\mathrm{b}}$ negative transfectants. The function of the native promoters of both the endogenous and the transfected
\end{abstract}

class I genes was found to be preserved in the transfectants as assessed by the response to stimulation with interferon- $\tau$. The present study was unable to confirm the reports of RIN specific lysis by $T$ cells from multiple low dose streptozotocin diabetic mice. Even in the presence of the syngeneic restriction element no lysis was observed. We conclude, that rat insulinoma cells clone $5 \mathrm{AH}-\mathrm{B}$, are able to integrate a foreign class I antigen gene and express the encoded product functionally. The data also suggest the possibility of creating major histocompatibility antigen positive rat insulinoma cells which are $R T 1^{g}$ negative. Such transfectants will be of great potential value for the dissection of cell mediated B cell destructive processes.

Key words: RIN-cells, gene-transfection, MHC-antigens, streptozotocin, cytotoxicity, T cells.
An $\mathrm{X}$-ray induced rat insulinoma [1] has given rise to a series of cell lines [2-4] very widely used for experimental diabetes research. Nevertheless, for some immunological studies these cell lines often pose a serious problem. They all share the rare rat major histocompatibility complex (MHC) haplotype RT1' of the New England Deaconess Hospital (NEDH) rat which harboured the original tumour and, as such, they constitute either an allogeneic or xenogeneic cell line when used in studies of cell mediated B cell destruction. This severely limits their use. Consequently it would be a great advantage if it was possible to change them into "syngeneic" cells of a desired MHC haplotype. In the present study we therefore introduce an efficient method for transfection

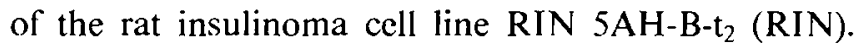
Using this method we were able to study whether RIN cells could express an introduced $\mathrm{H}-2$ class I antigen in a functional manner, and how expression possibly affects the recognition of RIN cells by lymphocytes isolated from multiple low dose streptozotocin diabetic mice.

\section{Materials and methods}

\section{Animals}

16-week old $\mathrm{C} 3 \mathrm{H}$ and $\mathrm{C} 57 \mathrm{Bl} / 6$ mice were purchased from the Charles River Breeding Laboratories, (Sulzfeld, FRG) and were allowed to acclimatize for at least a week before use in experimental work. NEDH rats were from our own brecding colony at the Hagedorn Research Laboratory. All animals wcre kept under standard conditions and fed ad libitum. The haplotype of the major histocompatibility complex for the $\mathrm{C} 3 \mathrm{H}$ and $\mathrm{C} 57 \mathrm{Bl} / 6$ mice are $\mathrm{H}-2^{\mathrm{k}}$ and $\mathrm{H}-2^{\mathrm{b}}$, respectively, while for the NEDH rat it is RTIz.

\section{Cell lines}

The insulin producing rat insulinoma cell line RIN $5 A H-B-t_{2}$ of haplotype RT.1 ${ }^{g}$ [4] was a kind gift of I)r. J. H. Nielsen, Hagedorn Research Laboratory. The murine thymoma cell line EL-4Bu, haplotype $\mathrm{H}-2^{\mathrm{b}}$ ( $\Lambda$ TCC TIB 40) and the rat plasmacytoma cell line IR $983 \mathrm{~F}$, haplotype RT. $1^{\mathrm{u}}$ [5] served as haplotype specific targets in the ${ }^{51} \mathrm{Cr}$-release assays. The RIN-K $K^{b} 1.3$ and $R I N-K^{b} 1.9$ cell lines are RIN cells stably transfected by electroporation with a $10 \mathrm{~kb}$ genomic fragment encoding the class I major histocompatibility antigen gene $H-2 K^{b}[6]$ in- 


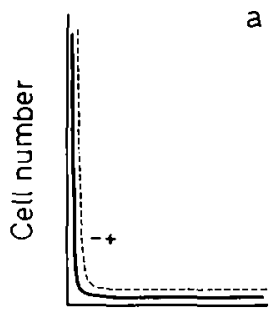

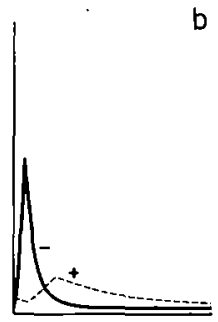

b

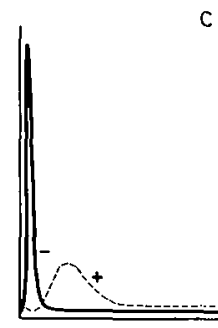

Fluorescence intensity
Fig. 1 a-c. Fxpression of the $\mathrm{H}-2 \mathrm{~K}^{\mathrm{b}}$ molecule on the surface of transfected RIN cells. RIN $5 \Lambda \mathrm{H}-\mathrm{B}$ cclls (a), and two transfected cell lines, RIN-K $K^{b} 1.3$ (b) and RIN-K 1.9 (c) were stained by indirect immunofluorescence using the $\mathrm{mAb} 28.8 .6 \mathrm{~S}$ and analysed by floweytometry. The fluorescence activated cell sorter (FACS) profiles show the expression of $\mathrm{H}-2 \mathrm{~K}^{\mathrm{b}}$ on the cell lines, when cultured in the absence (-) or in the presence (-.-) of $10 \%$ IF $-\gamma$ containing L12R4 supernatant for $24 \mathrm{~h}$ before analysis. The FACS profiles show the number of cells in a population as a function of the fluorescence intensity. In a all the cells are clustered around channels 1 to 5 , establishing the fluorescence intensity distribution of negative controls. In $b$ and $c$ positively stained cells appear at channels above 5

serted in the pJNL-1 vector [7]. This vector has 6 unique cloning sites and carries, besides an easy selection system for use in prokaryotic cells, the dominant selection marker of neomycin resistance, which in eukaryotic cells confers resistance to the drug G418. The mouse L12R4 [8] and EL-4,16.4 [9] thymoma cell lines (a kind gift of Dr. B. Rubin, Institute for Experimental Immunology) were used for the production of interferon- $\gamma$ or interleukin-2 (IL-2) containing supernatants, respectively. The RIN cell lines were grown in Dulbecco's modified Eagles medium (DMEM) supplemented with $10 \%$ fetal calf serum (FCS), L-glutamine ( $2 \mathrm{mmol} / \mathrm{l})$, sodium pyrovate $(1 \mathrm{mmol} / \mathrm{l})$, penicillin $(100 \mathrm{u} / \mathrm{ml})$ and streptomycin $(100 \mu \mathrm{g} / \mathrm{ml})$, with the extra addition of the selective drug Geneticin $418(G 418)(250 \mu \mathrm{g} / \mathrm{ml})$ for growth of the transfected RIN cell lines. The plasmacytoma and thymoma cell lines were grown in RPMI-1640 medium supplemented as above for DMEM, except for the addition of sodium pyrovate. All tissue culture media and additives were purchased from Gibco Ltd., (Paisley, Scotland, UK) and all tissue culture plasticware from Teknunc, (Roskilde, Denmark).

\section{DNA procedures}

All DNA procedures were carried out essentially as described by Maniatis et al. [10]. Restriction endonucleases were used according to the specifications given by the manufacturers of restriction enzymes (Boehringer Mannheim, Mannheim, $\mathrm{FRG}$ and New England Biolabs, Beverly, Mass., USA).

\section{Transfection procedure}

The only transfection method found to be effective (efficiency of approximately $10^{-5}$ stably transfected cell clones/surviving cells $10 \mu \mathrm{g}$ DNA) was electroporation. This method requires an electroporation apparatus which is able to deliver a short high voltage pulse to the cells that are going to be transfected. The apparatus used was constructed according to a slightly modified version of the diagram published by Chu et al. [11]. The basic design of the apparatus is very simple, the circuit allows the capacitors to be charged from an external power supply and then discharged through the cell suspension via the platinum electrodes. The apparatus can be charged with maximally $300 \mathrm{~V}$ and the capacitance can be set to either $500 \mu \mathrm{F}$ or $1000 \mu \mathrm{F}$. Farad $\left(\mathrm{F}=\mathrm{m}^{-2} \mathrm{~kg}^{-1} \mathrm{~s}^{2} \mathrm{C}^{2}\right)$ is a constant for a given capacitor and determines together with the voltage applied the amount of electrical charge the capacitor can be loaded with. Growing RIN cells, $50-70 \%$ confluent, were harvested by trypsinization, counted, and $1.5 \cdot 10^{6}$ cells resuspended in $500 \mu \mathrm{l} \mathrm{Ca}^{2-1-}$ - and $\mathrm{Mg}^{2+}$-free phosphate buffered saline solution (PBS) (Gibco) in a sterile disposable plastic microcuvette containing $10 \mu \mathrm{g}$ plasmid DNA. The cells were kept at $4^{\circ} \mathrm{C}$ for $10 \mathrm{~min}$ and then exposed to a single voltage pulse $(200 \mathrm{~V}$, $500 \mathrm{uF}$ ). The cells then remained in the buffer at $4^{\circ} \mathrm{C}$ for an additional $10 \mathrm{~min}$ before being transferred to $250 \mathrm{ml}$ tissue culture flasks containing prehcated medium.

\section{Selection of stable transfectants}

$\Lambda$ fter 2 days in normal medium, stably transfected cells were selected using $500 \mu \mathrm{g} / \mathrm{ml}$ of the drug G418 for 6 days, whereafter only a few surviving cells could be seen. Further sclection was performed at a maintenance dose of $250 \mu \mathrm{g} / \mathrm{ml}$. Analysis for expression of the transfected $\mathrm{H}-2 \mathrm{~K}^{\mathrm{b}}$ gene was performed on the fluorescence activated cell sorter (FACS) analyser using the monoclonal antibody 28.8.6S.

\section{Tcell cultures}

Allo- and xeno-immune cytotoxic $T$ cells were generated by immunization of $\mathrm{C} 3 \mathrm{H}$ mice i.p. with $10^{8}$ splenocytes suspended in $100 \mu \mathrm{l} \mathrm{PBS}$ from cither $\mathrm{C} 57 \mathrm{Bl} / 6$ mice or $\mathrm{NEDH}$ rats, respectively. The splenocytes were pretreated with $50 \mu \mathrm{g} / \mathrm{ml}$ Mitomycin C (Sigma, St. Louis, Mo, US $\Lambda$ ) for $30 \mathrm{~min}$ at $37^{\circ} \mathrm{C}$. Control mice werc given buffer only. After 3 weeks the allo- and xenoimmune mice were killed by cervical dislocation and the spleens were excised. Single cell suspensions werc prepared and the erythrocytcs were lysed in $155 \mathrm{mmol} / 1 \quad \mathrm{NH}_{4} \mathrm{Cl}, 10 \mathrm{mmol} / \mathrm{L} \quad \mathrm{KHCO}_{3}, 0.1 \mathrm{mmol} / \mathrm{l}$ $\mathrm{Na} 2 \mathrm{EDTA}$ (cthylenediaminctetraacetic acid). $2 \cdot 10^{7}$ primed spleen cells were cultured for 5 days in $20 \mathrm{ml}$ RPMI 1640 medium sup plemented with additional non-essential amino acids (Gibco), 5\% FCS, $10 \mathrm{mmol} / \mathrm{l}$ MOPS (3-N-morpholino-propanesulfonic acid, Sigma), $50 \mu \mathrm{mol} / \mathrm{I} \beta$-mercaptoethanol, together with an equal number of Mitomycin $\mathrm{C}$ treated $\mathrm{C} 3 \mathrm{H}$ splenocytes as antigen presenting cells and $10 \cdot 10^{6}$ Mitomycin $C$ treated splenocytes of the appropriate type as stimulator cells. A second in vitro stimulation was performed cssentially as described above, except that only $5 \cdot 10^{6}$ effector cells were used and the medium was supplemented with either $10 \%$ human recombinant interlcukin-2 (rIL-2) or a $10 \%$ dilution of a mouse IL-2 containing cell culture supernatant, obtained from EL-4, 16.4 cells [9].

\section{${ }^{51}$ Cr-release assay}

The ability of ${ }^{51} \mathrm{Cr}$-labelled transfected and untransfected cells to serve as targets for recovered viable allo- and xeno-rcactive T cells was assayed and percentagc of specific release calculated essentially as described in detail by MacKay et al. [12]. The major differences being that our assays were carried out in triplicate as a $3 \mathrm{~h}$ release assay using $1 \mathrm{~mol} / 1 \mathrm{HCl}$ to obtain maximal lysis.

\section{Induction of diabetes}

Mice were rendered diabetic according to the procedure used by McEvoy et al. [13, 14]: $\mathrm{C} .57 \mathrm{Bl} / 6$ male mice with a weight of $24-26 \mathrm{~g}$ were given one daily injection i.p. of $45 \mathrm{mg}$ streptozotocin (STZ) $/ \mathrm{kg}$ body weight in $200 \mu \mathrm{l} 0.1 \mathrm{~mol} / \mathrm{l}$ sodium-citrate buffer $\mathrm{pH} 4.5$ for 5 consecutive days. The STZ was injected within $10 \mathrm{~min}$ of dissolution. Control mice received citrate buffer only. STZ was purchased from The Upjohn Company, (Kalamazoo, Mich., USA). Blood was 
withdrawn from the orbital vein for measurement of the nonfasting glucose concentration by a Hypocount MX B glucose analyser ( $\mathrm{Hy}$ poguard Ltd., Woodbridge, UK). The mice were killed 11 days after the final injection, and splcen cells were prepared and assayed for cytotoxicity as described above.

\section{Enhancement of $M H C$ class I expression}

Mouse interferon- $\gamma$ (IFN- $\gamma$ ) was obtained as cell culture supernatant by culturing the thymoma cell line I..12R4 in the presence of Phorbol 12-Myristate 13-Acetate (Sigma, St. Louis, MO, USA). Enhancement of $\mathrm{MHC}$ class I antigen expression was acquired by growing the RIN cells and the RIN-K $\mathrm{K}^{\mathrm{b}}$ transfectants in the presence of $10 \% \mathrm{~L} 12 \mathrm{R} 4$ supernatant for $24.72 \mathrm{~h}$. The enhancement was measured by FACS analysis.

\section{FACS-analysis}

The analysis for expression of endogenous rat class I MHC antigens and the transfected mouse class I $\mathrm{MHC}$ antigen $\mathrm{H}-2 \mathrm{~K}^{\mathrm{b}}$ was carried out as an indirect immunofluorescence analysis using a Fluorescence Activated Cell Sortcr (FACS IV, Becton Dickinson, Mechelen, Bclgium). Expression of rat class I was detected using the monoclonal antibody (mAb) OX-18 (Serotec Ltd., Oxford, LK) recognizing a monomorphic determinant of rat RT1A class I antigen, whereas mouse $\mathrm{H}-2 \mathrm{~K}^{\mathrm{h}}$ was detected by the monoclonal antibodies $20.8 .4 \mathrm{~S}$ and $28.8 .6 \mathrm{~S}$ recognizing shared determinants between $\mathrm{D}^{\mathrm{b}}, \mathrm{K}^{\mathrm{b}}, \mathrm{K}^{\mathrm{d}}$ and $\mathrm{D}^{\mathrm{b}}, \mathrm{K}^{\mathrm{b}}$, respecitvely $[15]$ and $\mathrm{K} 7.65$ recognizing a $\mathrm{K}^{\mathrm{b}}$ specific determinant [16]. Briefly, the cells were trypsinized off for $2 \mathrm{~min}$ at $37^{\circ} \mathrm{C}$, then DMEM with $10 \%$ FCS was added to neutralize the tryp$\sin$. The cells were pelleted at $200 \mathrm{~g}$ for $5 \mathrm{~min}$ and resuspended in PBS, $1 \%$ bovine serum albumin (BSA) (Sigma, St. Louis, Mo, USA), $5 \mathrm{mmol} / 1 \mathrm{NaN}_{3}$, whercafter they were reacted with the appropriate $\mathrm{mAb}$ at $4^{\circ} \mathrm{C}$ for $30 \mathrm{~min}$ and washed twice in PBS, $1 \% \mathrm{BS} \Lambda$, $5 \mathrm{mmol} / 1 \mathrm{NaN}_{3}$. Subsequently, cells were reacted with the secondary fluorescein-conjugated $\mathrm{F}\left(\mathrm{ab}^{\prime}\right)_{2}$ rabbit anti-mouse $\lg \mathrm{G}$ antibody (Dakopatts, Glostrup, Denmark) under the same conditions as above. After incubation, the cells were washed twice before analysis. On analysis, the cells were gated on the forward light scatter peak Mean fluorescence intensities were calculated on a PDP 11 (Digital Equipment Corporation, Maynard, Mass, USA) computer using the FCSDX7 software which gives a mean channel number of the analysed cell population.

\section{Statistical analyses}

Differences between groups were established by Students t-test for unpaircd samples.

\section{Results}

\section{Antibody reactivity}

RIN cells were successfully transfected with the mouse $\mathrm{H}-2 \mathrm{~K}^{\mathrm{h}}$ gene by electroporation and a number of stably growing clones were selected in G418. RIN-K $\mathrm{K}^{\mathrm{b}} 1.3$ and RIN-K $K^{\mathrm{b}} 1.9$ stained positive with the mAb $28.8 .6 \mathrm{~S}$ showing mean fluorescence intensities of 22.0 and 13.8 , respecitvely, compared to 4.4 of the non-transfected RIN cells (Fig. 1). Likewise, the mAb's K7.65 and 20.8.4S did react with the transfectants, but not with the untransfected RIN cells (data not shown).

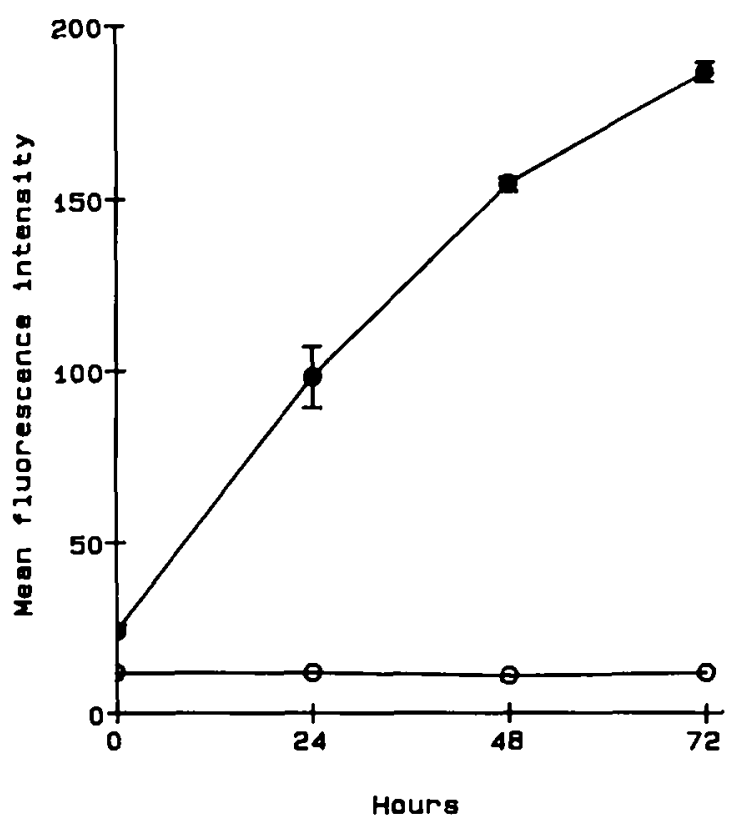

Fig. 2. Correlation between expression of the $\mathrm{H}-2 \mathrm{~K}^{\mathrm{b}}$ antigen and the time of incubation in the presence of IFN- $\gamma$. RIN $5 \Lambda \mathrm{H}$-B cells $(O)$ and RIN-K 1.9 cells $(\odot)$ were cultured ${ }^{\mathrm{b}}$ the presence of $10 \%$ IFN $-\gamma$ containing L12R4 supernatant for the indicated time periods. After staining by indirect immunofluorescence, using the $\mathrm{mAb}$ 28.8.6S, the cells were analysed by flowcytometry. The values given are mean fluorescence intensity (arbitrary units), and represents the means of duplicate samples. Error bars indicate $1 \times$ S. D. Fluorescence intensity of RIN-K $\mathrm{K}^{\mathrm{b}} 1.9$ is significantly higher than RIN $5 \wedge \mathrm{H}$ B. $p<0.01$ for $0 \mathrm{~h} ; p<0.005$ for $24 \mathrm{~h}, p \leq 0.0001$ for $48 \mathrm{~h}, p<0.0002$ for $72 \mathrm{~h}, n=2$

\section{Effect of IFN-\%}

The ability of L12R4 cell culture supernatant containing mouse IFN- $\gamma$ to enhance endogenous rat class I MHC expression in RIN cells was tested by FACS analysis, using the mAb OX-18. The MHC class I antigen expression was found to increase by the addition of up to $10 \%$ L12R 4 cell culture supernatant, whereafter no further increase in the expression could be accomplished (data not shown).

Likewise, the correlation with incubation time was tested (Fig. 2). The RIN-K ${ }^{\mathrm{b}} 1.9$ transfectant was incubated with $10 \%$ L12R4 cell culture supernatant and $K^{b}$ expression was monitored on the FACS analyser after 0, 24, 48 and $72 \mathrm{~h}$ of incubation, using the $\mathrm{mAb} 28.8 .6 \mathrm{~S}$. A marked increase in the level of $\mathrm{K}^{\mathrm{b}}$ expression was observed with increasing incubation time, reaching a near maximal level after $72 \mathrm{~h}$. At this time a 10 -fold increase in $\mathrm{K}^{\mathrm{b}}$ expression was observed.

The effect of IFN-y on the expression of the transfected $\mathrm{K}^{\mathrm{b}}$ gene is also visualized in Figure 1, where the FACS profiles of the untransfected RIN cells and the stably transfected $\mathrm{RIN}-\mathrm{K}^{\mathrm{b}} 1.3$ and RIN-K $\mathrm{K}^{\mathrm{b}} 1.9$ clones are depicted for cells grown either in the presence or the absence of IFN- $y$. The addition of IFN- $\gamma$ did not affect the mean fluorescence intensity of 4.4 for the untransfected RIN cells, but it boosted the $\mathrm{K}^{\mathrm{b}}$ expression from 


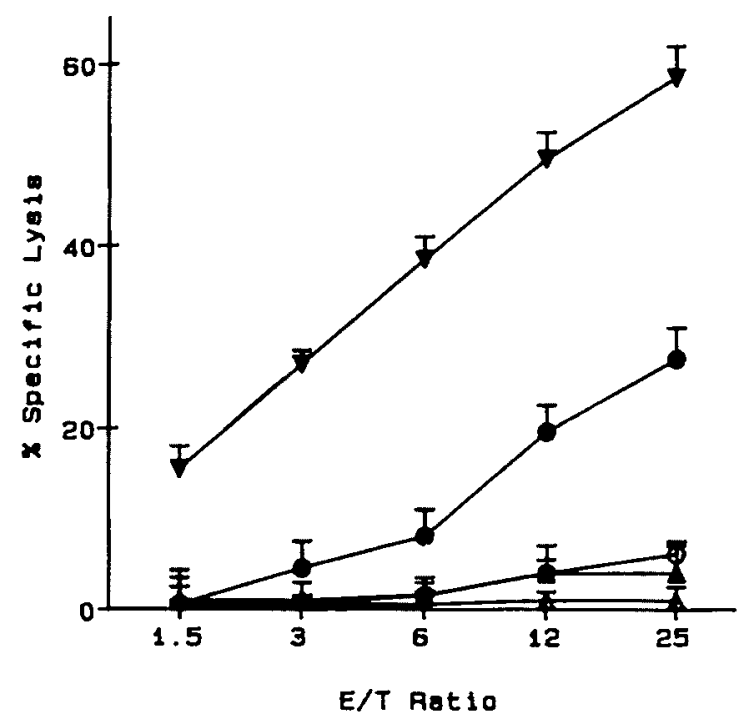

Fig. 3. Allospecific cytotoxic $\mathrm{T}$ cell mediated lysis of $\mathrm{H}-2 \mathrm{~K}^{\mathrm{b}}$ expressing target cells. Effector cells are $\mathrm{C} 3 \mathrm{H}$ anti-C.57Bl/ 6 cytotoxic $\mathrm{T}$ cells. ${ }^{51}$ Cr-labelled targets cells are RIN $5 A H-B(\Delta), \operatorname{RIN} 5 A H-B^{1 F N-\gamma}(\Delta)$,

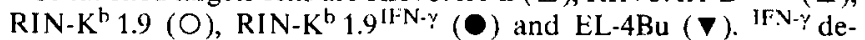
notes $72 \mathrm{~h}$ treatment of target cells with $10 \%$ IFN- $\gamma$ containing L12R4 supernatant. Specific lysis $(\%)$ is calculated as (observed release minimal release) (maximal release - minimal release) 100 . Error bars indicate $1 \times \mathrm{S} . \mathrm{D}$., $n=3$. At an effector to target ratio of $25 \mathrm{RIN}$ $\mathrm{K}^{\mathrm{bIFN}-\gamma}$ is lysed significantly above RIN $5 \mathrm{AH}-\mathrm{B}^{\mathrm{IFN}-\gamma}, p<0.001$ and RIN-K $K^{b}$ is lysed significantly above RIN SAH-B, $p<0.02$

22.0 to 103.3 for the RIN-K $\mathrm{K}^{\mathrm{b}} 1.3$ clone and from 13.8 to 74.0 for the RIN-K $\mathrm{K}^{\mathrm{b}} 1.9$ clone.

Recognition and lysis of labelled target cells by cytotoxic T lymphocytes (CTL's): Alloreactive CTL's (C3H anti-C57Bl/6) recognized and lysed the $\mathrm{K}^{\mathrm{b}}$ positive RIN-K ${ }^{b} 1.9$ cells whereas $K^{b}$ negative RIN cells were not recognized/lysed (Fig.3). At an effector to target $(\mathrm{E} / \mathrm{T})$ ratio of $25: 1, \mathrm{RIN}-\mathrm{K}^{\mathrm{b}} 1.9$ cells showed a specific lysis of $6.0 \pm 1.5 \%$ compared to $1 \pm 1.3 \%$ specific lysis of RIN cells. When the target cells had been stimulated with IFN- $\gamma$ for $24 \mathrm{~h}$ an increased lysis was observed for the RIN-K $\mathrm{K}^{\mathrm{b}} 1.9$ cells $(28.0 \pm 3.5 \%)$ compared to only $4 \pm 2.8 \%$ for RIN cells. The $\mathrm{K}^{\mathrm{b}}$ positive control cell line EL-4Bu was also lysed effectively $(58.3 \pm 3.3 \%)$.

All RIN cells, regardless of $\mathrm{K}^{\mathrm{b}}$ phenotype, were susceptible to lysis by xenospecific CTL's (C3H antiNEDH) (Fig. 4). At the E/T ratio of $25: 1$, RIN cells exhibited $14.5 \pm 1 \%$ lysis and $\mathrm{RIN}-\mathrm{K}^{\mathrm{b}} 1.9$ only $3.5 \pm 1.5 \%$ lysis, which is comparable to the lysis of the negative control IR983F of $4.5 \pm 1.5 \%$. Treatment with IFN- $\gamma$ of the RIN and RIN-K 1.9 target cells increased the specific lysis to $49.5 \pm 2.5 \%$ and $56 \pm 3.5 \%$, respectively.

The degree of rat MHC class I expression on the target cells for the xenoreactive CTL's was assessed by FACS analysis using the mAb OX-18. Mean fluorescence intensities obtained were 52 for RIN, 93 for RIN treated with IFN- $\gamma, 22$ for RIN-K ${ }^{\mathrm{b}} 1.9$ and 170 for RIN-K 1.9 treated with IFN- $\gamma$.

\section{Multiple low dose streptozotocin induced diabetes}

Hyperglycaemia was successfully induced in eight C57Bl/ 6 mice by administration of 5 injections of STZ. The plasma glucose levels at 11 days after the last injection had risen to $15.1 \pm 3.4 \mathrm{mmol} / \mathrm{l}$ in STZ treated mice compared to $7.4 \pm 0.6 \mathrm{mmol} / \mathrm{l}$ in mice given citrate buffer only. Splenocytes obtained 11 days after the last injection of STZ or citrate buffer were assayed for cytotoxic activity against $\mathrm{K}^{\mathrm{b}}$ positive and negative RIN cells. In no case was there any evidence for specific cellular cytotoxic activity against the RIN cells or the RIN-K ${ }^{\mathrm{b}} 1.9$ transfectant cells by these lymphocytes (Table 1). However, when RIN and RIN-K ${ }^{b} 1.9$ cells were cultured in the presence of interferon- $\gamma$ containing cell culture supernatant for $72 \mathrm{~h}$ before the cytotoxicity assay was performed, both STZ and control lymphocytes, were found to cause a low level of lysis of these targets (Table 1). Allospecific $\mathrm{C} 3 \mathrm{H}$ anti-C57Bl/6 and xenospecific $\mathrm{C} 3 \mathrm{H}$ anti-RIN CTL's serving as positive

Table 1. Assay for anti-RIN cytotoxic activity by mouse multiple streptozotocin injected (MSTZ)- and sham-derived lymphocytes

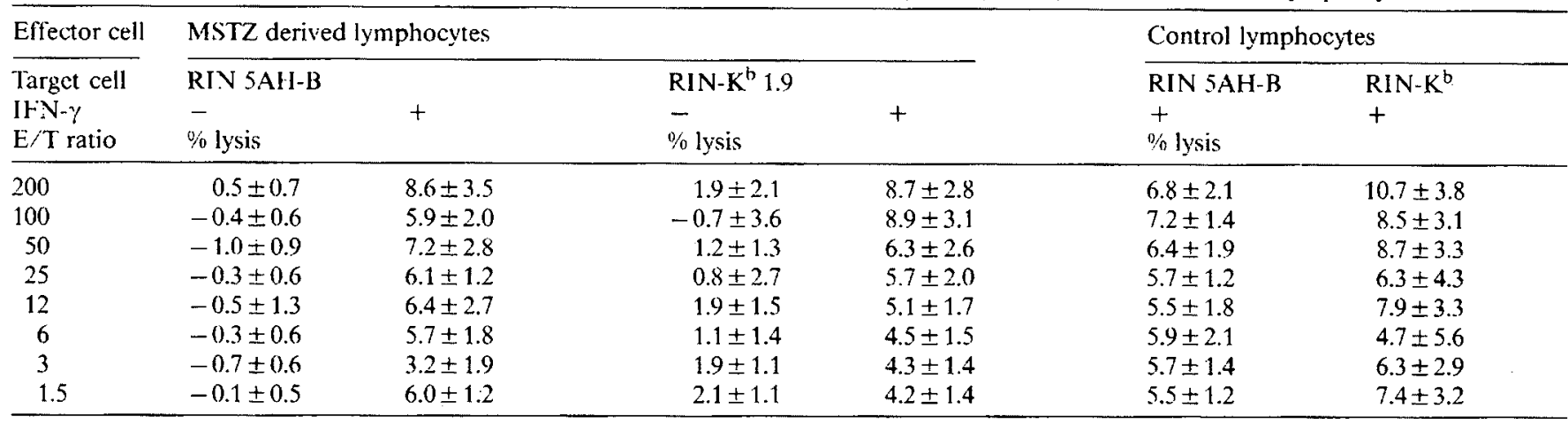

Effector cells are lymphocytes from C57Bl/6 mice taken on day 11 after the final injection of streptozotocin (MSTZ) or buffer alone (control). Target cells are ${ }^{51} \mathrm{Cr}$-labelled RIN $5 \Lambda \mathrm{H}-\mathrm{B}$ or RIN-Kb 1.9 cells either unstimulated $(-)$ or stimulated $(+)$ for $72 \mathrm{~h}$ prior to assay with IFN- $\gamma$. Positive controls: At an effector to target $(\mathrm{E} / \mathrm{T})$ ratio of $25: 1 \mathrm{C} 3 \mathrm{H}$ anti-RIN CTL's specifically lysed IFN- $\gamma$ stimulated RIN cells to $35.5 \pm 2.8 \%$ and $\mathrm{C} 3 \mathrm{H}$ anti-C57Bl/6 CTL's lysed IFN- $\gamma$ stimulated RIN-K 1.9 to $28.0 \pm 3.5 \%$. Specific lysis of the target cells ( $\%$ ) is calculated as (observed release - minimal release)/(maximal release - minimal release) $100.1 \times \mathrm{S}$. I). of the populations are indicated. Specific lysis of target cells by MSTZ derived lymphocytes are not significantly above lysis by control lymphocytes 
controls lysed their IFN- $\gamma$ stimulated target cells efficiently. At an E/T ratio of 25:1 IFN- $\gamma$ stimulated RIN cells showed a specific lysis of $35.5 \pm 2.8 \%$ and $I F N-\gamma$ stimulated RIN-K ${ }^{\mathrm{b}} 1.941 .3 \pm 5.8 \%$.

\section{Discussion}

Transfection of eukaryotic cell lines has become a very fruitful method in the study of expression and function of many different genes and their products. MHC genes encoding class I and II antigens have been successfully studied employing this method [17, 18], however, no attempts have been reported earlier on the use of this method for studying cell mediated B cell autoreactivity in vitro. RIN cells have been used as antigen source and target cells in a series of studies designed to study $T$ lymphocyte mediated autoreactivity $[12-14,19-22]$ and concern about the influence of the foreign MHC haplotype of the RIN cells has been raised [13, 14]. This report describes the first experiments designed to overcome this problem by creating RIN cells syngeneic for a single $\mathrm{MHC}$ gene. We have successfully introduced the mouse $\mathrm{H}-2 \mathrm{~K}^{\mathrm{b}}$ gene together with a selection marker $\left(\mathrm{G} 418^{\mathrm{R}}\right)$ into the RIN cell genome by electroporation. Several stably transfected cell clones have been selected, two of which are described in this paper, RIN$\mathrm{K}^{\mathrm{b}} 1.9$ and RIN-K $\mathrm{K}^{\mathrm{b}} 1.3$.

The plasmid pJNL-K ${ }^{b} 9$ used for the transfection of the RIN cells contain the $\mathrm{H}-2 \mathrm{~K}^{\mathrm{b}}$ gene including approximately $2 \mathrm{~kb}$ of $5^{\prime}$-flanking sequences known to contain IFN $-\gamma$ responsive elements [23] inserted in the pJNL-1 vector [7]. The expression of endogenous rat class I antigens is found to be induced by mouse IFN- $\gamma$ in RIN m5F cells [24]. When testing the transfectants it was found that responsiveness towards mouse IFN- $\gamma$ was retained for both the transfected $\mathrm{H}-2$ gene (Figs. 1 and 2) and the endogenous RT1 gene (data not shown). IFN- $\gamma$ was not able to induce any de novo expression of $\mathrm{H}-2 \mathrm{~K}^{\mathrm{b}}$ like protein on the surface of untransfected RIN cells under the conditions which enhance the expression of the $\mathrm{H}-2 \mathrm{~K}^{\mathrm{b}}$ antigen 5 -fold in the transfectants (Fig.1). Identical results were obtained using rat IFN- $\gamma$ (data not shown).

Expression of the transfected $\mathrm{H}-2 \mathrm{~K}^{\mathrm{b}}$ gene was not expected to affect the expression of the endogenous $\mathrm{RT}^{\mathrm{g}}$ gene. Surprisingly, an inverse relationship in the amounts of expression of the two class I genes was observed when measured by flowcytometry using the RT1 class I specific antibody $\mathrm{OX}-18$ and the $\mathrm{K}^{\mathrm{b}}$ reactive antibody $28.8 .6 \mathrm{~S}$. In $\mathrm{K}^{\mathrm{b}}$ positive cell clones expression of the RT $1^{g}$ molecule was down-regulated, whereas this was not the case in $\mathrm{K}^{\mathrm{b}}$ negative cell clones. However, the down-regulation was overcome by IFN- $\gamma$ stimulation (data not shown). This decreased expression is not likely to be caused by the transfection procedure or the growth in selective medium, since the $G 418^{R}$ RIN-K ${ }^{b}$ negative clones did not exhibit this decrease. The cause

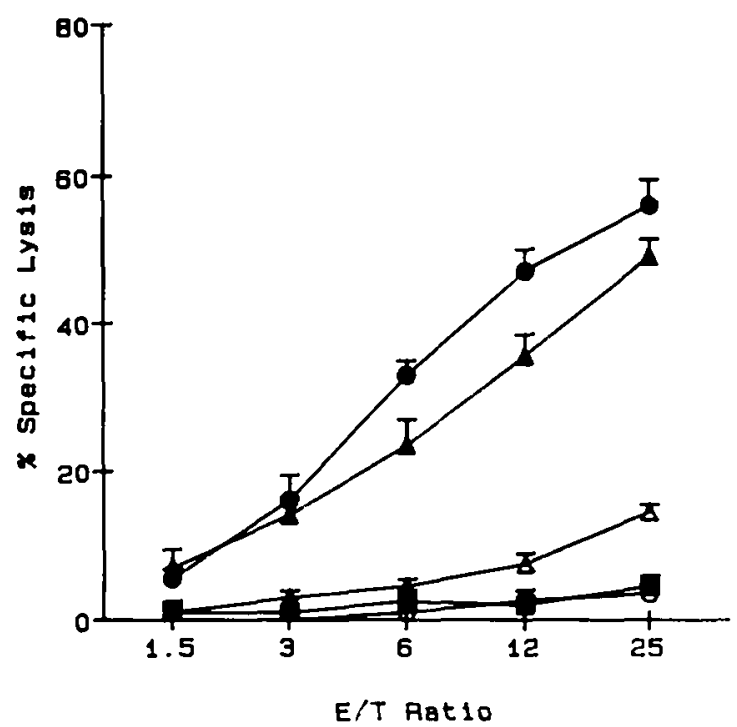

Fig. 4. Xenospecific cytotoxic $T$ cell mediated lysis of $R T 1^{g}$ expressing target cells. Effector cells are $\mathrm{C} 3 \mathrm{H}$ anti-NEDH rat cytotoxic $\mathrm{T}$ cells. ${ }^{51} \mathrm{Cr}$-labelled target cells are RIN $5 \mathrm{AH}-\mathrm{B}(\triangle)$, RIN $5 A \mathrm{H}-\mathrm{B}$ IF $N-\gamma(\Delta)$, RIN-K $1.9(O), R I N-K^{b} 1.9^{I F N-\gamma}(\bullet)$ and IR983F ( ). IF $\mathrm{N}-\gamma$ denotes $72 \mathrm{~h}$ treatment of target cells with $10 \%$ IFN $-\gamma$ containing L12R4 supernatant. Specific lysis (\%) is calculated as (observed release - minimal release)/(maximal release minimal relcase) 100 . Error bars indiate $1 \times \mathrm{S}$. D., $n=3$. $\Lambda \mathrm{t}$ an effector to target $(\mathrm{E} / \mathrm{T})$ ratio of 25 both RIN-K ${ }^{\text {bIF.N- } \gamma}$, RIN $5 A H-B^{I F, \gamma-\gamma}$ and RIN $5 A H-B$ are lysed significantly above IR983F, $p \leq 0.0001, p \leq 0.0001$ and $p .<0.0005$, respectively. $R I N-K^{b}$ is not significantly above $I R 983 \mathrm{~F}$

could be competition either for transcriptional factors required for class I expression [25] or for $\beta_{2}$-microglobulin which associates with the class I heavy-chain posttranslationally and is necessary for its expression on the cell surface [26]. However, competition for a transcriptional factor appears least likely, since $G 418^{\mathrm{R}} \mathrm{RIN}-\mathrm{K}^{\mathrm{h}}$ negative clones were not affected in spite of the fact that they probably also contain the $5^{\prime}$-flanking region. Future experiments will hopefully answer these questions.

An all or none response was observed when the transfectants were tested for expression of $\mathrm{H}-2 \mathrm{~K}^{\mathrm{b}}$ using three different $\mathrm{K}^{\mathrm{b}}$ reactive mAb's (data not shown). Since the mAb's recognize different epitopes $[15,16]$ it could be assumed that the $\mathrm{H}-2 \mathrm{~K}^{\mathrm{b}}$ molecule are expressed faithfully on the $\mathrm{K}^{\mathrm{b}}$ positive transfectants. However, to verify this result at a functional level anti$\mathrm{K}^{\mathrm{b}}$ specific cytotoxic $\mathrm{T}$ cells were raised. The $\mathrm{K}^{\mathrm{b}}$ positive EL-4Bu cell line and the IFN- $\gamma$ stimulated RIN$\mathrm{K}^{\mathrm{b}} 1.9$ transfectant were very efficiently lysed by the CTL's whereas unstimulated RIN-K ${ }^{\mathrm{b}} 1.9$ cells as well as untransfected RIN cells irrespective of IFN- $\gamma$ stimulation were not (Fig. 3). It is not surprising that the unstimulated RIN-K ${ }^{b} 1.9$ transfectant was not lysed when the low level of $\mathrm{K}^{\mathrm{b}}$ expression is taken into consideration (Fig. 1). IFN- $\gamma$ stimulation of the RIN-K ${ }^{b} 1.3$ and $-K^{b} 1.9$ cells for $24 \mathrm{~h}$ is found to bring about a 5 -fold increase in expression of the transfected gene (Fig. 1) which is enough to make the stimulated RIN transfectants a suitable target for the CTL's (Fig.3). Thus, the unresponsiveness of the CTL's towards the unstimu- 
lated RIN-K $\mathrm{K}^{\mathrm{b}} 1.9$ cells is not due to faulty expression of the $\mathrm{H}-2 \mathrm{~K}^{\mathrm{b}}$ molecules but merely the result of a subthreshold concentration of target molecules $\left(\mathrm{H}-2 \mathrm{~K}^{\mathrm{b}}\right)$ on the cell surface not able to trigger the specific CTL's.

The effect of decreased expression of the endogenous rat class I antigen was also observed functionally in ${ }^{51} \mathrm{Cr}$-release assays (Fig.4). C3H anti-NEDH CTL's mediated lysis of unstimulated RIN cells whereas the transfectant RIN- $K^{\mathrm{b}} 1.9$ and the negative control cell line, the plasmacytoma IR983F, were not lysed. As expected, if the absent lysis was not due to an altered RT1 product but to a decreased expression, stimulation with IFN- $\gamma$ increased the CTL mediated lysis of RIN and RIN-K ${ }^{\mathrm{b}} 1.9$ cells 3 - to 15 -fold, respectively. Thus, the $\mathrm{RT}^{\mathrm{s}}$ molecule is expressed faithfully by the transfectant but to a lesser degree.

McEvoy et al. [13, 14], have demonstrated the presence of cell mediated anti-RIN activity in lymphocytes obtained from mice made diabetic by multiple injections of streptozotocin (MSTZ). The lysis observed was not due to natural killer cell activity although it was MHC unrestricted [14], so the mediator cells are likely to be CTL's. This result is very surprising, since CTL's normally recognize only cells expressing fragmented foreign antigens in the context of syngeneic MHC class I molecules, which function as restriction elements [27]. However, CTL's can also react towards foreign MHC class I antigens, in the so-called allo- and xenogeneic responses [28]. Using RIN cells for the immunization of mice in order to raise $B$ cell specific $T$ cells, we have found that the CTL mediated lysis of the RIN cells was directed against the RT1's molecule on the RIN cells and not against a RIN/B cell specific antigen. This result made it possible, that the effect observed by McEvoy et al. [13,14] actually was, at least in part, a xeno-specific response directed against the foreign class I molecule and not a RIN cell specific antigen. McEvoy et al. briefly mentioned the possibility of a xenogeneic effect and the need for syngeneic target cells. We were therefore very attracted by the possibility of investigating this aspect using this RIN-K ${ }^{\mathrm{b}} 1.9$ transfectant expressing the $\mathrm{H}-2 \mathrm{~K}^{\mathrm{b}}$ antigen in a functional manner as a "pseudo-syngeneic" target cell. For this purpose $\mathrm{C} 57 \mathrm{Bl} / 6$ male mice were made diabetic in accordance with the procedure used by McEvoy et al. [13, 14]. However, we were not able to reproduce the results obtained by this group. Neither the untransfected RIN cells nor the transfectant were lysed by the MSTZ derived lymphocytes (Table 1). After $72 \mathrm{~h}$ stimulation with IFN- $\gamma$ a low level of lysis of all target cells was observed, but this reactivity was not confined to the MSTZ derived lymphocytes alone, since "control lymphocytes" derived from animals only receiving buffer reacted similarly (Table 1 ). Neither did the lysis decrease by decreasing $\mathrm{E} / \mathrm{T}$ cell ratio as expected for a specific lysis. It appears that IFN- $y$ confers some kind of unspecific general vulnerability towards lysis by lymphocytes.

Our unsuccessfull attempts to repeat McEvoy et al.'s
$[13,14]$ results might be due to differences in the timing of the analysis for cytotoxicity or in the RIN cell lines used. McEvoy et al. [13] found maximal cytotoxic activity of the splenocytes against RIN cells on day 11 (approx $9 \%$ specific lysis) after the first STZ injection. Our cytotoxicity assays were carried out at day 16 using their designation. At day 16 they report a decreased specific lysis of $5 \%$ [13]. However, this value is still significantly above their control, so we would expect to be able to find an elevated cytotoxicity even on day 16 , if present in our study. Another difference between the present study and the work by McEvoy et al. $[13,14]$ is the use of different cell lines. They have used the RINm5F [2] and we the RIN 5AH-B [4] cell line and it is possible that these lines express different unique antigens of importance for the recognition by lymphocytes from MSTZ mice. However, we believe that the use of RIN cell lines transfected with syngeneic MHC molecules in respect to effector cell haplotype will gain a wide distribution in research or cell mediated $B$ cell specific reactivity. Our results point to the possibility of making real syngeneic RIN cells using super-transfection or transfection with MHC genes under stronger constitutive promoters, since we have found that the endogenous RT1 class I gene is down-regulated upon transfection with the $\mathrm{H}-2 \mathrm{~K}^{\mathrm{b}}$ gene, if the transfected gene is expressed. Another possibility of creating real syngeneic RIN cells is to select a RT1 negative variant and then transfect this RIN cell line with the MHC gene of interest.

Acknowledgements. Dr. B. Rubin is thanked for helpful discussions and the donation of the cell lines L-12R4 and EL-4.16.4. Dr. J. Høriis Nielsen is acknowledged for contributing the RIN 5AH-B-t $t_{2}$ cell line. Dr. A. Lernmark is greatly acknowledged for his continuous support. P.S. was the recipient of a scholarship from the Foundation Nordisk Insulinlaboratorium, Gentofte, Denmark and J.S. was the recipient of stipends from the Danish Medical Research Council (J.no's. 12-5758 and 12-6426).

\section{References}

1. Chick WL, Warten S, Chute RN, Like AA, Lauris V, Kitchen KC (1977) A transplantable insulinoma in the rat. Proc Natl Acad Sci USA 74: 628-632

2. Gazdar AF, Chick WL, Oie HK, Sims HL, King DL, Weir GC, Lauris V (1980) Continuous, clonal, insulin- and somatostatin-secreting cell lines established from a transplantable rat islet tumor. Proc Natl Acad Sci USA 77: 3519. 3523

3. Madsen OI), Larsson L-I, Rehfeld JF, Schwartz TW, Lernmark Ä, I abrecque $\Lambda D$, Steiner DF (1986) Cloned cell lines from a transplantable islet cell tumor are heterogeneous and express cholecystokinin in addition to islet cell hormones. J Cell Biol 103: 2025-2034

4. Niclsen JH (in press) Mechanisms of pancreatic cell growth and regeneration: Studies on rat insulinoma cells. Exp Clin Endocrinol

5. Barin $H$, Xhurdibisse L-M, Burtonboy $G$, Lebasq $\Lambda$-M, Clercq LD, Cormont F (1984) Rat monoclonal anbodies. I. Rapid purification from in vitro culture supernatants. $\mathrm{J}$ Immunol Methods 66 : 261-269 
6. Weiss E, Golden I, Zakut R, Mellor A, Fahrner K, Kvist S, Flavell RA (1983) The DN $\wedge$ sequence of the $K^{b}$ gene: Fividence for gene conversion as a mechanism for the gencration of polymorphism in histocompatibility antigens. F.MBO J 2: 453-462

7. Schøller J (1988) Construction of a novel eukaryotic transfection vector, pJNL-1. Nucl Acids Res 16:769

8. Rubin B, Rieninger 1, Suzan M, Fueri J, Denizot F, Landolfo S, Gamble J, Lonai P (1984) On the molecular basis of Thelper cell function. III. B-lymphocyte promotor factors: production by Thybridoma and tumor cells; preliminary biochemical characterization. Scand J Immunol 19:563 573

9. Denizot F, Rubin B (1985) Murine and human $T$ cell factors that induce the differentiation of normal mouse lymphocytes into cytotoxic cells copurify with interleukin 2. Scand J Immunol 22: 401-413

10. Maniatis T, Fritsch EF, Sambrook J (1982) Molecular cloning, A laboratory manual. 1st edn. Cold Spring Harbor Laboratory Cold Spring Harbor, New York

11. Chu G, Hayakawa H, Berg P (1987) Elcctroporation for the efficient transfection of mammalian cells with DNA. Nucl Acids Res 15: $1311-1326$

12. MacKay P, Boulton A, Rabinovitch A (1985) Lymphoid cells of $\mathrm{BB} / \mathrm{W}$ diabetic rats are cytotoxic to islet beta cells in vitro. Diabetes 34: 706-709

13. McEvoy RC, Andersson J, Sandler S, Hellerström C (1984) Multiple low dose streptozotocin-induced diabetes in the mouse. $\mathrm{J}$ Clin Invest 74: 715.722

14. McEvoy RC, Thomas NM, Hellerström C, Ginsberg-Fellner F, Moran TM (1987) Multiple low dose streptozotocin-induced diabetes in the mouse: further evidence for involvement of an anti- $B$ cell cytotoxic cellular autoimmune response. Diabetologia 30: 232238

15. Ozato K, Sachs DH (1981) Monoclonal antibodies to mouse $\mathrm{MHC}$ antigens III. Hybridoma antibodies reacting to antigens of the $\mathrm{H}-2^{\mathrm{b}}$ haplotype reveal genetic control of isotype expression. $\mathrm{J}$ Immunol 126: 317-321

16. Hämmerling GJ, Rüsch $\Gamma$, Tada N, Kimura $S$, Hämmerling U (1982) Localization of allodeterminants on $\mathrm{H}-2 \mathrm{~K}^{\mathrm{b}}$ antigens determined with monoclonal antibodics and $\mathrm{H}-2$ mutant mice. Proc Natl $\Lambda$ cad Sci USA 79:4737. 4741

17. Scholler J, Shimonkevitz R, MacDonald HR, Kvist S (1986) Different structural constraints for recognition of mouse $\mathrm{H}-2 \mathrm{~K}^{\mathrm{d}}$ and $-\mathrm{K}^{\mathrm{K}}$ antigens by alloimmune cytolytic $\mathrm{T}$ lymphocytes. J Exp Med 164: $1823-1834$

18. Germain RN, Malissen B (1986) Analysis of the expression and function of class II major histocompatibility complex-encoded molecules by DNA-mediated gene-transfer. Ann Rev Immunol 4: 281-315

19. Kolb H, Ben-Nun A, Cohen IR, Barberena I, Kicsel U (1985) Autoimmune T-lymphocytes with specificity for pancreatic islet antigens. Immunol Lett $9: 29-32$

20. Prud'homme GJ, Fuks A, Colle E, Guttmann RD (1984) Isolation of T-lymphocyte lines with specificity for islet ccll antigens from spontaneously diabetic (insulin dependent) rats. Diabetes 33: $801-803$

21. Prud'homme GJ, Colle E, Fuks A, Guttmann RI) (1987) Major histocompatibility complex restriction of T-lymphocyte responses to islet cell antigens in IDDM rats. Diabetes 36:237-239

22. Prud'homme GJ, Fuks A, Guttmann RD, Colle F: (1986) T cell hybrids with specificity for islet cell antigens. J Immunol 136: 1535-1536

23. Fellous M, Nir U, Wallach D, Merlin $G$, Rubinstein M, Revel M (1982) Interferon-dependent induction of mRNA of the major histocompatibility complex antigens in human fibroblasts and lymphoid cells. Proc Natl Acad Sci USA 79: 3082-3086

24. Campbell II, Harrison LC, Colman PG, Papiannou J, Ashcroft RG (1986) Expression of class I MHC proteins on RIN m5F cells is increased by IF $\mathrm{N}-\gamma$ and lymphokine-conditioned medium. Diabetes 35: 1225-1228

25. Shirayoshi Y, Miazaki J, Burke PA, Hamada K, Apella F, Ozato K (1987) Binding of multiple nuclcar factors to the $S^{\prime}$ upstream regulatory element of the murine major histocompatibility class I gene. Mol Cell Biol 7: 4542-4548

26. Sege K, Rask L, Peterson PA (1981) Role of $\beta_{2}$-microglobulin in the intracellular processing of $\mathrm{HLA}$ antigens. Biochemistry 20: 45234530

27. Zinkernagel RM, Doherty PC (1974) Restriction of an in vitro $T$ cell mediated cytotoxicity in lymphocytic choriomeningitis within a syngeneic or semi-allogeneic system. Nature 248: 701702

28. Lindahl KF, Bach FH (1975) Human lymphocytes recognize mouse alloantigens. Nature 254: 607609

Received: 25 January 1989

and in revised form: 11 April 1989

Dr. J.Schøller

Institute of Fxperimental Immunology

University of Copenhagen

Norre Alle 71

DK-2100 Copenhagen $\varnothing$

Denmark 